\title{
Fluoride in the Bones of Foxes (Vulpes vulpes Linneaus, 1758) and Raccoon Dogs (Nyctereutes procyonoides Gray, 1834) from North-Western Poland
}

\author{
Mirona Palczewska-Komsa • Elzbieta Kalisińska • Danuta I. Kosik-Bogacka • \\ Natalia Lanocha - Halina Budis • Irena Baranowska-Bosiacka • \\ Izabela Gutowska • Dariusz Chlubek
}

Received: 28 February 2014 / Accepted: 13 May 2014 / Published online: 30 May 2014

(C) The Author(s) 2014. This article is published with open access at Springerlink.com

\begin{abstract}
Assessment of exposure to fluoride (F) is increasingly focused on mineralized tissues, mainly bones. Their periodic growth and continuous reconstruction make them a good material for studying long-term $\mathrm{F}^{-}$accumulation. In this study, $\mathrm{F}^{-}$concentrations were determined in the bones of foxes and raccoon dogs from north-western Poland and relationships between bone $\mathrm{F}^{-}$and the age categories of the animals were attempted to be identified. Bone samples were collected from femurs of 32 foxes ( 15 males and 17 females) and 18 raccoon dogs (10 males and 8 females) from polluted, medium-polluted, and unpolluted by $\mathrm{F}^{-}$areas. Bone $\mathrm{F}^{-}$was determined by potentiometric method, and results were expressed per dry weight (dw); they ranged from 176 to $3,668 \mathrm{mg} / \mathrm{kg} \mathrm{dw}$ in foxes and from 84 to $1,190 \mathrm{mg} / \mathrm{kg} \mathrm{dw}$ in raccoon dogs. Foxes from northwestern Poland accumulated much more $\mathrm{F}^{-}$in their bones than raccoon dogs. Our study shows that the assessment of hazards created by industrial emitters can be conducted conveniently by the measurements of fluorine content in hard tissues of wild animals. Due to availability of such type of material for studies, it seems that the analysis of fluoride content in bones can be a good tool in the development of ecotoxicology.
\end{abstract}

Communicated by D. I. Kosik-Bogacka

M. Palczewska-Komsa • E. Kalisińska • D. I. Kosik-Bogacka ( $\square)$ • N. Lanocha $\cdot$ H. Budis

Department of Biology and Medical Parasitology, Pomeranian Medical University, Powstanców Wlkp. 72, 70-111 Szczecin, Poland e-mail: kodan@pum.edu.pl

I. Baranowska-Bosiacka $\cdot$ I. Gutowska $\cdot$ D. Chlubek

Department of Biochemistry and Medical Chemistry, Pomeranian

Medical University, Powstanców Wlkp. 72, 70-111 Szczecin, Poland

I. Gutowska

Department of Biochemistry and Human Nutrition, Pomeranian

Medical University, Broniewskiego 24, 71-460 Szczecin, Poland
Keywords Fluoride $\cdot$ Bone $\cdot$ Red fox $\cdot$ Raccoon dog . Bioaccumulation

\section{Introduction}

Fluoride $\left(\mathrm{F}^{-}\right)$, depending on the concentration, can have a moderately positive or toxic effect on living organisms. Among other things, $\mathrm{F}^{-}$is involved in the biosynthesis of enzymes (adenylyl cyclase and HMG) and the mineralization of hard tissue and cartilage $[1,2]$. Its deficiency may lead to disturbances in the binding of calcium, magnesium, and phosphorus in bones as well as hypomagnesaemia, both leading to bone demineralization. In contrast, excess $\mathrm{F}^{-}$can cause fluorosis of the teeth, and in extreme cases, bone fluorosis and bone tumors [3-6]. An estimated toxic $\mathrm{F}^{-}$dose for humans is $5 \mathrm{mg} / \mathrm{kg}$ body weight [7].

Ecotoxicological studies aiming at the indirect assessment of environmental pollution by various substances, for example $\mathrm{F}^{-}$, include the determination of concentrations in living organisms. Their concentrations are mainly determined in the organs responsible for the detoxification process, i.e., the liver and kidneys of mammals and birds. However, some of them, including $\mathrm{F}^{-}$, over time accumulate in increasing quantities in highly mineralized tissues. Therefore, for several decades, researchers have used this type of bone tissue to enable the assessment of long-term environmental pollution with $\mathrm{F}^{-}$[8].

Biomonitoring of the environmental threat associated with $\mathrm{F}^{-}$pollution is usually based on bone and tooth samples collected from herbivorous ungulates and small laboratory mammals. However, medium-sized omnivorous mammals seem to be more suitable, as their diet and longevity make is more similar to humans; these are, for example, Canidae: fox (Vulpes vulpes) and raccoon dogs (Nyctereutes procyonoides). 
Although both species have a number of traits that make them potentially good bioindicators, as mentioned by Apostoli [9], little data exists on the $\mathrm{F}^{-}$concentrations in the mineralized tissues of foxes [10-12], and there is no data on the $\mathrm{F}^{-}$ concentration in the bones of raccoon dogs.

The fox (Vulpes vulpes, Linneaus, 1758) has wild populations in Eurasia, the northern part of Africa and North America, and areas of Australia and New Zealand [13, 14]. Foxes are omnivorous, but their diet is dominated by food of animal origin, such as voles, shrews, mice, moles, birds, chicks and eggs, occasional hares or rabbits, frogs, lizards, invertebrates, and carrion. In addition, the fox feeds on berries and fruits and is also often seen looking for food in garbage dumps and landfills $[13,15]$.

The raccoon dog (Nyctereutes procyonoides, Gray, 1834) comes from north-western Asia and inhabits areas of eastern Siberia, northern China, Manchuria, Korea, Japan, and the former Soviet Union [16]. Its diet includes small mammals (voles), carrion, fish, eggs, aquatic birds, molluscs, amphibians, reptiles, insects, earthworms, berries, grains, and plant shoots [15, 17-19]. This is an expansive species due to its high adaptability to environmental conditions and its omnivorous feeding habits. The raccoon dog was introduced into the Soviet Union in the 1920s, which led to a rapid migration to areas of western and northern Europe [16, 17, 20]; in Poland, the first raccoon dogs appeared in the 1950s [16, 21].

The aforementioned characteristics of the fox and raccoon dog (omnivorous diet, common occurrence, and presence in a given area throughout the year) predispose them to being potentially good bioindicators in the intermediate evaluation of environmental $\mathrm{F}^{-}$pollution.

The aims of the study were to determine the $\mathrm{F}^{-}$concentrations in femur compact bone of foxes and raccoon dogs from north-western Poland, to compare their bone $\mathrm{F}^{-}$levels against background domestic and environmental conditions, and to identify possible existing relationships between the $\mathrm{F}^{-}$concentrations in bones and the age categories of the analyzed animals. Moreover, a further aim of this study was evaluate the usefulness of the examined wild canids as bioindicators of environmental $\mathrm{F}^{-}$pollution.

\section{Material and Methods}

\section{Study Area}

The material was collected in an area contaminated with $\mathrm{F}^{-}$ ( $<20 \mathrm{~km}$ from the source of $\mathrm{F}^{-}$emission; polluted area); an area in the southern part of the West Pomerania, moderately polluted with $\mathrm{F}^{-}\left(>20 \mathrm{~km}\right.$ from the source of $\mathrm{F}^{-}$emission; medium-polluted area); and an area of the Warta Mouth National Park (WMNP, 8,074 ha), Lubuskie province (unpolluted area) (Fig. 1).
In the West Pomerania province, mainly its capital Szcze$\operatorname{cin}\left(53^{\circ} 25^{\prime} 57^{\prime \prime} \mathrm{N}, 14^{\circ} 33^{\prime} 19^{\prime \prime} \mathrm{E}\right)$, there are or has been a number of industrial plants - sources of $\mathrm{F}^{-}$emission into the environment (Fig. 1). In addition, there is also a refinery in Schwedt in Germany, located near the German-Polish border, which has no less impact on the environment than the plants in Poland, taking into account the prevailing winds in Western Pomerania. Furthermore, the $\mathrm{F}^{-}$waste from the plants is often discharged to wastewater and into rivers and then into the drinking water. The Gunica River near the Police Chemical Plant SA has at least 10 times higher $\mathrm{F}^{-}$concentration compared to most Polish rivers [22, 23].

The area of Warta Mouth National Park (WMNP, 8,074 ha) is periodically inundated by the waters of the Warta and Odra Rivers (Polish/Czech: Odra; German: Oder). The Warta flows into the Odra near Kostrzyn $\left(52^{\circ} 35^{\prime} \mathrm{N} ; 14^{\circ} 40^{\prime} \mathrm{S}\right)$, a city in western Poland. The Odra is the second largest river in Poland, constituting a large section of the Polish-German border. River sediments collected from the Odra and Warta Rivers in the vicinity of Kostrzyn contain elevated levels of heavy metals, including $\mathrm{Hg}[24,25]$. The concentration of $\mathrm{Hg}$ in the sediments of the Odra ranged from 0.25 to $1.49 \mathrm{mg} / \mathrm{kg}$ in Kostrzyn [25].

\section{Material}

Femurs were collected from 32 foxes (15 males and 17 females). The foxes were divided into two groups: foxes from a polluted $(n=10)$ and medium-polluted $(n=13)$ by $\mathrm{F}^{-}$areas. The foxes were qualified into one of two age categories (immature or adult) according to measurements of canine teeth in accordance with the work of Knowlton and Whittemore [26]. The foxes were classified as immature (im) when aged 10-12 months $(n=16)$ and adult (ad) when over the age of 12 months $(n=16)$.

Femurs were also obtained from 18 raccoon dogs ( 10 males and 8 females). The animals were sourced from two groups: raccoon dogs from polluted $(n=4)$ and unpolluted $(n=14)$ by $\mathrm{F}^{-}$areas. The raccoon dogs were divided into two groups: specimens weighing $<4.5 \mathrm{~kg}(n=8)$ were considered immature and with the weight $>4.5 \mathrm{~kg}(n=10)$ were classified as adult [27].

Preparation of Material for Chemical Analysis and Determination of Fluoride

After the removal of remaining ligaments and muscles, the samples were stored frozen at $-20{ }^{\circ} \mathrm{C}$ until analysis. In analysis, the compact bone was used. The samples were dried to constant weight in an oven at $105^{\circ} \mathrm{C}$. The percentage of water content in the samples was determined by gravimetric method. The dried samples were ground in an agate mortar. Samples weighing $\sim 1 \mathrm{~g}$ were mixed with $1 \mathrm{ml}$ of perchloric acid and 
Fig. 1 Map of Poland including the study area in West Pomeranian voivodship (WP V) and Lubuskie voivodship $(L V)$ with plants, electricity, and refinery emitting fluorides and direction of predominant winds (arrow)

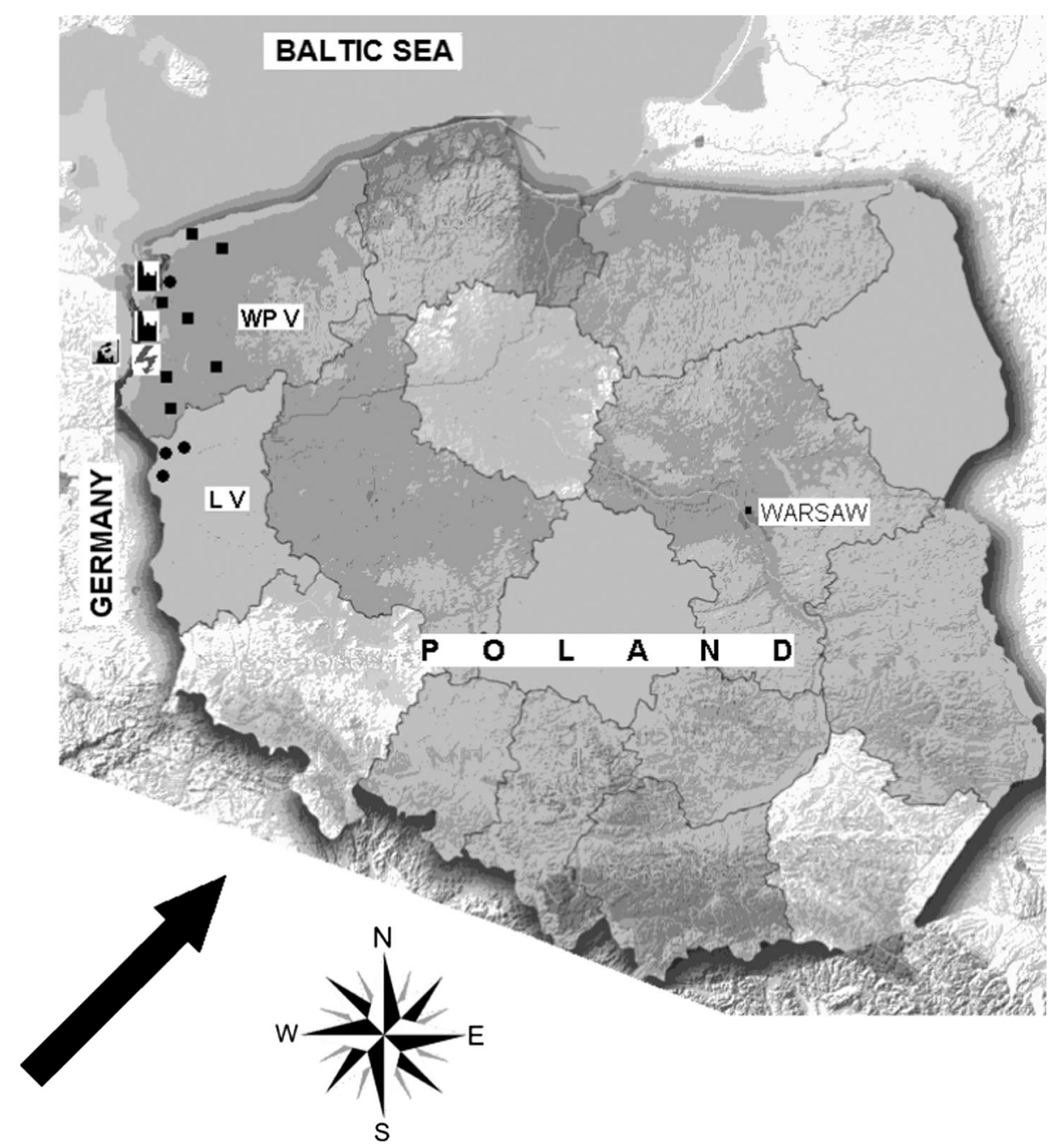

shaken at $90{ }^{\circ} \mathrm{C}$ for $1 \mathrm{~h}$. After cooling, $0.5 \mathrm{ml}$ sample was transferred to a plastic tube, and then to $2 \mathrm{ml}$ of sodium citrate solution and $2.5 \mathrm{ml}$ of TISAB II. Reagent solutions were prepared with highly purified water (PURELAB Option Elga). Determination of the $\mathrm{F}^{-}$concentration was performed by potentiometry with ion-selective Orion electrodes (Thermo Scientific, USA). $\mathrm{F}^{-}$content in the sample was calculated based on the potential difference measured in each sample, the sample weight, and the concentration of the added standard. After mixing, the potential difference of each sample was measured for $10 \mathrm{~min}, 5 \mathrm{~min}$ before the addition of the appropriate standard and $5 \mathrm{~min}$ after the addition. Details of the analytical procedure are presented in the work by Gutowska et al. [28-30].

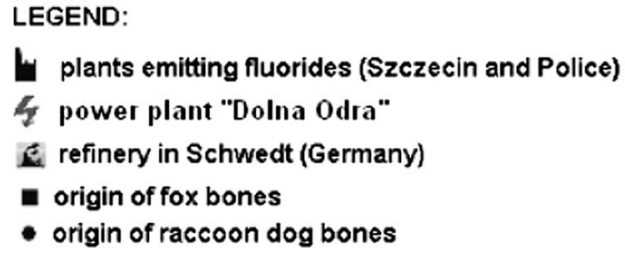

The correctness of the analytical procedure was controlled by determining the concentration of $\mathrm{F}^{-}$in materials with known concentrations, i.e., standard $\mathrm{NaF}$ solutions at concentrations of $0.1,1$, and $10 \mathrm{mg} / \mathrm{kg}$ (Orion Company, USA).

\section{Statistical Analysis}

Statistical analysis was performed using STATISTICA 10.0 software (StatSoft) and Microsoft Excel 2007. It included determination of the average $\mathrm{F}^{-}$concentration in the bones of the examined species. Arithmetic means (AM), standard deviations (SD) from AM and medians (Med) were calculated. Compliance of distributions of $\mathrm{F}^{-}$levels with normal distribution was checked using a Kolmogorov-Smirnov test 
with Lilliefors correction. The distribution of bone $\mathrm{F}^{-}$concentrations in foxes and raccoon dogs was not normal $(\mathrm{K}-\mathrm{S}=0.2$, $p<0.01$ for foxes; $\mathrm{K}-\mathrm{S}=0.2, p<0.05$ for raccoon dogs). Therefore, further statistical analysis used a nonparametric Mann-Whitney $U$ test (M-W U). All comparisons were only performed for groups where the number of specimens was $n \geq 4$.

\section{Results}

Comparison of bone $\mathrm{F}^{-}$concentrations in samples collected from all animals showed a significant difference between the species $(U=161, p<0.01)$. In foxes, it was approximately $64 \%$ higher than in raccoon dogs (Table 1 ).

Comparisons were made within sex and age groups of the animals (Table 1). Statistically significant differences were found between male foxes and male raccoon dogs. The median bone $\mathrm{F}^{-}$in samples taken from male foxes was about two times higher than in male raccoon $\operatorname{dogs}(U=15, p<0.001)$. Statistical differences were also found between young male foxes and young male raccoon $\operatorname{dogs}(U=8, p<0.03)$ and between adult individuals (including males and females) of foxes and raccoon dogs $(U=16, p<0.004$; Table 1$)$.

$\mathrm{F}^{-}$concentration range in the compact femoral bone of foxes was $175.9-3,668.1 \mathrm{mg} / \mathrm{kg}$ dry weight $(\mathrm{dw})$. The greatest median $\mathrm{F}^{-}$concentration was observed in young males and the lowest in adult females (Table 1), but a comparison using a M$\mathrm{W}$ test showed no statistical significance.

The $\mathrm{F}^{-}$concentration range in the femoral compact bone of raccoon dogs was in the range $83.7-1,190.3 \mathrm{mg} / \mathrm{kg} \mathrm{dw}$. The greatest median $\mathrm{F}^{-}$was found in adult females and the lowest in young females (Table 1). In young females, raccoon dogs' median $\mathrm{F}^{-}$was about three times lower compared to adult females. Median $\mathrm{F}^{-}$concentrations in the bones of adult males were $174 \%$ lower compared to adult females

Comparing the two species of canids collected in the same area, a statistically significant difference in the bone $\mathrm{F}^{-}$was recorded only in bones of foxes and raccoon dogs coming from polluted areas $(U=4, p<0.03)$; median $\mathrm{F}^{-}$concentration in the bones of fox proved to be more than two times lower in raccoon dog (Table 2).

The bones of foxes coming from a polluted area were characterized by a greater $\mathrm{F}^{-}$concentration than foxes from medium-polluted area, and the difference was statistically significant (Table 2).

We also analyzed differences in bone $\mathrm{F}^{-}$between raccoon dogs from polluted and unpolluted areas. Median $\mathrm{F}^{-}$concentrations in the bones of raccoon dogs from both areas were similar, and no statistically significant difference was observed (Table 2).

\section{Discussion}

The analysis of the content of chemical elements in tissues, like bones or teeth, is an important tool in toxicological and ecological examinations because of their ability to accumulate large quantities of elements including various trace elements and fluorine. Fluorine constitutes a part of fluoroapatites and hence stimulates both bone hardness and resilience [20,21], as well as enamel solubility in teeth $[18,21]$.

In literature, $\mathrm{F}^{-}$concentrations in bone are given per dry weight or in ash. To be able to make comparisons with our results (expressed in mg per $\mathrm{kg} \mathrm{dw}$ ), we used our own calculations and the works of Lanocha et al. [31] and Budis et al. [32] to convert units. It was assumed that the average water content in the compact bone of Canidae is $23 \%$. In most publications, bone $\mathrm{F}^{-}$concentration is given as the arithmetic mean or a range of values, so in the comparison of our results with literature data, we use arithmetic means instead of medians.

There are few papers on bone $\mathrm{F}^{-}$concentrations in wild canids. Kay et al. [33] analyzed $\mathrm{F}^{-}$concentration in the bones of coyote Canis latrans in areas of North America not contaminated with $\mathrm{F}^{-}$. In coyotes from Montana (USA), the mean $\mathrm{F}^{-}$concentration in the mandible was $321 \mathrm{mg} / \mathrm{kg} \mathrm{dw}$ (Table 3), almost two times less than in the femurs of wild canids (foxes and raccoon dogs) from the polluted and medium-polluted areas in north-western Poland and 1.5 times lower than the bone $\mathrm{F}^{-}$concentration in raccoon dogs from an unpolluted area (Warta Mouth National Park) observed in our study.

In Europe, research on bone $\mathrm{F}^{-}$concentrations in canids was carried out in the UK by Walton [12], in mandibles of two groups of foxes living in areas with different degrees of $\mathrm{F}^{-}$ pollution. In foxes from uncontaminated areas, the mean $\mathrm{F}^{-}$ concentration in their mandibles was $283 \mathrm{mg} / \mathrm{kg} \mathrm{dw}$, several times smaller than in the mandibles of foxes inhabiting a nearby aluminum plant (Anglesey) which emits significant amounts of $\mathrm{F}^{-}(1,650 \mathrm{mg} / \mathrm{kg} \mathrm{dw})$ (Table 3). $\mathrm{F}^{-}$concentration in the mandibles of foxes in the vicinity of Anglesy was almost 1.7 times higher than in the femurs of foxes $(978 \mathrm{mg} / \mathrm{kg}$ $\mathrm{dw}$ ) and almost 5 times greater than the mean $\mathrm{F}^{-}$concentration in the femurs of raccoon dogs $(333 \mathrm{mg} / \mathrm{kg} \mathrm{dw})$ from polluted area observed in our study. $\mathrm{F}^{-}$level in the mandibles of foxes from areas not contaminated with $\mathrm{F}^{-}$(Aberdeen) was 1.2 times smaller than in the bones of raccoon dogs obtained from unpolluted area in our study.

The differences we observed in $\mathrm{F}^{-}$concentrations in the examined canids may have resulted from the following: interspecific differences $\mathrm{F}^{-}$accumulation in tissues, a considerable differences in the number of animals, different habitats (including the degree of $\mathrm{F}^{-}$contamination), diet, and type of bone material obtained for testing. The results showed northwestern Poland is more contaminated with $\mathrm{F}^{-}$than corresponding areas of the US and the UK, and the fox and raccoon 
Table 1 The fluoride concentration $(\mathrm{mg} / \mathrm{kg} \mathrm{dw})$ in the bones of the foxes and raccoon dogs by gender and age category

\begin{tabular}{|c|c|c|c|c|}
\hline \multirow[t]{2}{*}{ Gender, age category } & \multirow[t]{2}{*}{ Statistical parameters } & \multicolumn{2}{|c|}{$\mathrm{F}^{-}$concentration in the bone } & \multirow[t]{2}{*}{ M-W U (foxes vs raccoon dogs) } \\
\hline & & Foxes & Raccoon dogs & \\
\hline \multirow[t]{2}{*}{$\mathrm{M}+\mathrm{F}, \mathrm{imm}+\mathrm{ad}$} & $\begin{array}{l}\mathrm{AM} \pm \mathrm{SD} \\
\text { Med }\end{array}$ & $\begin{array}{l}738.5 \pm 600.1 \\
607.9\end{array}$ & $\begin{array}{l}446.6 \pm 301.2 \\
371.6\end{array}$ & $U=161$ \\
\hline & $\begin{array}{l}\text { Min-max } \\
n\end{array}$ & $\begin{array}{l}175.9-3668.1 \\
32\end{array}$ & $\begin{array}{l}83.7-1190.3 \\
18\end{array}$ & $p<0.01$ \\
\hline \multirow[t]{2}{*}{$\mathrm{M}, \mathrm{imm}+\mathrm{ad}$} & $\begin{array}{l}\mathrm{AM} \pm \mathrm{SD} \\
\text { Med }\end{array}$ & $\begin{array}{l}902.4 \pm 802.4 \\
752.8\end{array}$ & $\begin{array}{l}340.3 \pm 151.2 \\
363.9\end{array}$ & $U=15$ \\
\hline & $\begin{array}{l}\text { Min-max } \\
n\end{array}$ & $\begin{array}{l}290.1-3668.1 \\
15\end{array}$ & $\begin{array}{l}103.2-598.0 \\
10\end{array}$ & $p<0.001$ \\
\hline \multirow[t]{2}{*}{$\mathrm{M}, \mathrm{imm}$} & $\begin{array}{l}\mathrm{AM} \pm \mathrm{SD} \\
\mathrm{Med}\end{array}$ & $\begin{array}{l}776.8 \pm 234.0 \\
772.0\end{array}$ & $\begin{array}{l}330.7 \pm 163.9 \\
363.9\end{array}$ & $U=8$ \\
\hline & $\begin{array}{l}\text { Min-max } \\
n\end{array}$ & $\begin{array}{l}500.2-1182.7 \\
6\end{array}$ & $\begin{array}{l}103.2-492.0 \\
4\end{array}$ & $p<0.03$ \\
\hline \multirow[t]{2}{*}{ M, ad } & $\begin{array}{l}\mathrm{AM} \pm \mathrm{SD} \\
\mathrm{Med}\end{array}$ & $\begin{array}{l}986.1 \pm 1036.0 \\
741.9\end{array}$ & $\begin{array}{l}346.7 \pm 157.9 \\
336.2\end{array}$ & $U=0$ \\
\hline & $\begin{array}{l}\text { Min-max } \\
n\end{array}$ & $\begin{array}{l}290.1-3668.1 \\
9\end{array}$ & $\begin{array}{l}171.8-598.0 \\
6\end{array}$ & $p<0.01$ \\
\hline \multirow[t]{3}{*}{$\mathrm{F}, \mathrm{imm}+\mathrm{ad}$} & $\begin{array}{l}\mathrm{AM} \pm \mathrm{SD} \\
\text { Med }\end{array}$ & $\begin{array}{l}593.9 \pm 295.2 \\
542.7\end{array}$ & $\begin{array}{l}579.6 \pm 67.8 \\
480.2\end{array}$ & NS \\
\hline & Min-max & $175.9-1105.9$ & $83.7-1190.3$ & \\
\hline & $n$ & 17 & 8 & \\
\hline \multirow[t]{3}{*}{$\mathrm{F}, \mathrm{imm}$} & $\begin{array}{l}\mathrm{AM} \pm \mathrm{SD} \\
\mathrm{Med}\end{array}$ & $\begin{array}{l}643.0 \pm 316.0 \\
581.1\end{array}$ & $\begin{array}{l}310.8 \pm 215.3 \\
280.9\end{array}$ & NS \\
\hline & Min-max & $175.9-1105.9$ & $83.7-598.0$ & \\
\hline & $n$ & 10 & 4 & \\
\hline \multirow[t]{3}{*}{$\mathrm{F}$, ad } & $\begin{array}{l}\mathrm{AM} \pm \mathrm{SD} \\
\mathrm{Med}\end{array}$ & $\begin{array}{l}523.9 \pm 269.8 \\
422.2\end{array}$ & $\begin{array}{l}848.3 \pm 348.7 \\
920.2\end{array}$ & NS \\
\hline & Min-max & $329.6-1062.6$ & $362.4-1190.3$ & \\
\hline & $n$ & 7 & 4 & \\
\hline \multirow[t]{3}{*}{$\mathrm{M}+\mathrm{F}, \mathrm{imm}$} & $\begin{array}{l}\mathrm{AM} \pm \mathrm{SD} \\
\mathrm{Med}\end{array}$ & $\begin{array}{l}693.2 \pm 269.8 \\
681.2\end{array}$ & $\begin{array}{l}320.8 \pm 177.4 \\
333.8\end{array}$ & NS \\
\hline & Min-max & $329.6-1062.6$ & $83.7-598.0$ & \\
\hline & $n$ & 16 & 8 & \\
\hline \multirow[t]{2}{*}{$\mathrm{M}+\mathrm{F}, \mathrm{ad}$} & $\begin{array}{l}\mathrm{AM} \pm \mathrm{SD} \\
\mathrm{Med}\end{array}$ & $\begin{array}{l}783.9 \pm 810.8 \\
536.5\end{array}$ & $\begin{array}{l}547.3 \pm 348.5 \\
411.7\end{array}$ & $U=16$ \\
\hline & $\begin{array}{l}\text { Min-max } \\
n\end{array}$ & $\begin{array}{l}290.1-3668.1 \\
16\end{array}$ & $\begin{array}{l}171.8-1190.3 \\
10\end{array}$ & $p<0.004$ \\
\hline
\end{tabular}

$A M$ mean, $S D$ standard deviation, $M e d$ median, $n$ number of individuals, $F$ female, $M$ male, imm immaturus, $a d$ adultus, $M-W U$, Mann-Whitney $U$ test, $p$ significance level, NS nonsignificant

dog exhibited a measurable response to the amount of $\mathrm{F}^{-}$in the environment.

It should be noted that wild canids showed distinct differences in their bone $\mathrm{F}^{-}$. A statistically significant difference was found between foxes and raccoon dogs from polluted and medium-polluted areas; foxes showed more than $60 \%$ greater $\mathrm{F}^{-}$concentration. In addition, a statistically significant difference was noted between foxes and raccoon dogs collected in the same area (polluted area); the mean $\mathrm{F}^{-}$concentration in the bones of foxes was almost three times higher compared to raccoon dogs (978 and $333 \mathrm{mg} / \mathrm{kg} \mathrm{dw}$, respectively). These results can be attributed to a different lifestyle and diet of these animals. The raccoon $\mathrm{dog}$, as the sole representative of the Canidae, experiences anabiosis in response to an insufficient quantity of food in the winter. In contrast, the fox intakes food throughout the year, constantly accumulating $\mathrm{F}^{-}$also in winter.

Bone $\mathrm{F}^{-}$in the foxes living in north-western Poland has also been researched by Kalisińska and Palczewska [10] and Kalisińska and Palczewska-Komsa [11]; the samples were collected from the first molar mandibular teeth in foxes. Kalisińska and Palczewska compared $\mathrm{F}^{-}$concentrations in 
Table 2 The fluoride concentration $(\mathrm{mg} / \mathrm{kg} \mathrm{dw})$ in the bones of the foxes and raccoon dogs by origin

\begin{tabular}{llll}
\hline Origin & Statistical parameters & \multicolumn{2}{l}{$\mathrm{F}^{-}$concentration in the bone } \\
\cline { 3 - 4 } & & Foxes & Raccoon dogs \\
\hline Szczecin and surroundings (polluted area) & $\mathrm{AM} \pm \mathrm{SD}$ & $978.3 \pm 995.8$ & $332.6 \pm 92.0$ \\
& $\mathrm{Med}$ & 747.4 & 336.2 \\
& Min-max & $290.1-3668.1$ & $242.0-417.0$ \\
& $n$ & 10 & 4 \\
Southern part of voivodship West Pomeranian & $\mathrm{AM} \pm \mathrm{SD}$ & $560.3 \pm 268.3$ & - \\
(medium-polluted area) & Med & 500.2 & \\
& Min-max & $175.9-1001.4$ & \\
Voivodship Lubuskie (unpolluted area) & $n$ & 13 & $479.2 \pm 333.9$ \\
& AM \pm SD & - & 371.6 \\
& Med & & $83.7-1190.3$ \\
\hline
\end{tabular}

$A M$ mean, $S D$ standard deviation, Med median, $n$ number of individuals living in the north-western Poland (all individuals aged $<20$ months in both provinces) had similar mean $\mathrm{F}^{-}$concentration in their teeth (almost $300 \mathrm{mg} / \mathrm{kg} \mathrm{dw}$ ), which may indicate a more or less uniform level of $\mathrm{F}^{-}$contamination in this part of Poland (Table 3). That value is similar to $\mathrm{F}^{-}$ concentration found in the femurs of young raccoon dogs in our study $(321 \mathrm{mg} / \mathrm{kg} \mathrm{dw})$, but more than two times lower than $\mathrm{F}^{-}$in the femurs of young foxes $(693 \mathrm{mg} / \mathrm{kg}$ $\mathrm{dw})$. Both the teeth and bones of canids were collected in approximately the same period, and the differences

Table 3 The fluoride $\left(\mathrm{F}^{-}\right)$concentration $(\mathrm{mg} / \mathrm{kg})$ in wild canid bone material from various parts of the world

\begin{tabular}{|c|c|c|c|c|c|c|c|c|}
\hline Place & Species & Tissue & Age & Gender & $\begin{array}{l}\text { No. of } \\
\text { animals }\end{array}$ & $\mathrm{F}^{-}(\mathrm{d}$ & dw or ash) & Source \\
\hline \multirow[t]{3}{*}{ Poland, West Pomeranian voivodship } & \multirow[t]{3}{*}{ Fox (Vulpes vulpes) } & \multirow[t]{7}{*}{$\begin{array}{l}\text { Teeth, first permanent } \\
\text { molars }\end{array}$} & $>20$ months, ad & \multirow[t]{7}{*}{$\mathrm{F}+\mathrm{M}$} & 14 & $\begin{array}{l}\mathrm{dw} \\
\text { Ash }\end{array}$ & $\begin{array}{l}532 \pm 169 \\
692 \pm 224\end{array}$ & {$[11]$} \\
\hline & & & $<20$ months, imm & & 20 & $\mathrm{dw}$ & $358 \pm 208$ & \\
\hline & & & & & & Ash & $461 \pm 266$ & \\
\hline \multirow[t]{2}{*}{ Poland, Pomeranian voivodeship } & & & $<20$ months, imm & & 7 & $\mathrm{dw}$ & 392 & \\
\hline & & & & & & Ash & 303 & \\
\hline \multirow[t]{2}{*}{ Poland, West Pomeranian voivodship } & & & & & 13 & $\mathrm{dw}$ & 312 & \\
\hline & & & & & & Ash & 241 & \\
\hline \multirow[t]{3}{*}{ Poland, West Pomeranian voivodship } & & \multirow[t]{3}{*}{$\begin{array}{l}\text { Teeth, first permanent } \\
\text { molars }\end{array}$} & \multirow[t]{3}{*}{ 6-20 months } & \multirow[t]{3}{*}{$\mathrm{F}+\mathrm{M}$} & 4 & $\begin{array}{l}\mathrm{dw} \\
\text { Ash }\end{array}$ & $\begin{array}{l}514 \pm 309 \\
672 \pm 401\end{array}$ & \multirow[t]{3}{*}[10]{} \\
\hline & & & & & 10 & $\mathrm{dw}$ & $389 \pm 242$ & \\
\hline & & & & & & Ash & $510 \pm 320$ & \\
\hline Great Britain, Wales & & \multirow[t]{4}{*}{ Mandible } & 28.8 months & $\mathrm{F}+\mathrm{M}$ & 103 & $\mathrm{dw}$ & 551 & \multirow[t]{4}{*}[12]{} \\
\hline $\begin{array}{l}\text { Great Britain, Anglesey } \\
\text { (excluding Holyhead) }\end{array}$ & & & 16.6 months & $\mathrm{F}+\mathrm{M}$ & 52 & $\mathrm{dw}$ & 476 & \\
\hline Great Britain, Aberdeen TN & & & - & $\mathrm{F}+\mathrm{M}$ & 19 & $\mathrm{dw}$ & 283 & \\
\hline $\begin{array}{l}\text { Great Britain, Anglesey, } \\
\text { Holyhead TZ }\end{array}$ & & & - & $\mathrm{F}+\mathrm{M}$ & 8 & $\mathrm{dw}$ & 1,650 & \\
\hline USA, Montana & Coyote (Canis latrans) & & - & - & 2 & $\mathrm{dw}$ & 321 & {$[31]$} \\
\hline
\end{tabular}

$F$ female, $M$ male, $a d$ adult, im immaturus, $d w$ dry weight 
are probably mainly due to differences in the chemical structure and composition of the tissues.

Indirect assessment of environmental $\mathrm{F}^{-}$pollution is usually based on the analysis of bone samples (especially the mandible) of long-lived large ungulate mammals, which are generally herbivorous [34-37]. In those animals, bone $\mathrm{F}^{-}$ depends on the area of occurrence and their age, and to a lesser extent, on the species and the type of bone selected for analysis. As Western Pomerania has chemical plants using minerals containing significant amounts of $\mathrm{F}^{-}$for the production of phosphoric acid and phosphate fertilizers (mainly Police and Szczecin), these areas are suitable for biomonitoring research of $\mathrm{F}^{-}$, usually carried out on cervids [34-37]. Gutowska et al. [34, 35] found that deer (Cervus elaphus) and roe deer (Capreolus capreolus) from areas remote from Szczecin agglomeration (Szczecinek, Połczyn Zdroj, and Swidwin) had bone $\mathrm{F}^{-}$concentrations not exceeding $300 \mathrm{mg} / \mathrm{kg} \mathrm{dw}$.

Zakrzewska et al. [36] conducted a study on the bones of deer from north-western Poland in the late 1990s, i.e., at the beginning of modernization of chemical plants in Police. Bone samples were collected from animals in an area more exposed to $\mathrm{F}^{-}$(I, western part of West Pomerania, including the areas of Szczecin and Police districts) and areas with much lower industrial pollution (II, the eastern part of the province). In deers originating from area II, bone $\mathrm{F}^{-}$levels were usually $20 \%$ lower $(\sim 245 \mathrm{mg} / \mathrm{kg} \mathrm{dw})$ compared to specimens in area I $(\sim 435 \mathrm{mg} / \mathrm{kg} \mathrm{dw})$. In our study, the mean bone $\mathrm{F}^{-}$concentrations in the bones of wild canids from the north-western Poland $(738 \mathrm{mg} / \mathrm{kg} \mathrm{dw}$ in fox and $447 \mathrm{mg} / \mathrm{kg} \mathrm{dw}$ in the raccoon dog) were higher than in deers investigated by Zakrzewska et al. [36] at least two decades previously. The results of these interspecific comparisons are in line with the observations of Kay et al. [33], who suggested that the omnivorous mammals (understood as an ecological group) accumulate more $\mathrm{F}^{-}$than herbivorous mammals.

We also analyzed the relationship between bone $\mathrm{F}^{-}$levels and the age of canines. Both Walton [12], who showed a correlation between bone $\mathrm{F}^{-}$and the age of foxes $(r=0.59$, $p<0.001)$ and Kalisińska and Palczewska [10] and Kalisińska and Palczewska-Komsa [11], who documented a relationship between fox tooth $\mathrm{F}^{-}$and age $(r=0.38, p<0.03)$, confirm this general regularity in long-lived mammals. However, in this study, although young foxes and raccoon dogs did have lower bone $\mathrm{F}^{-}$(693 and $321 \mathrm{mg} / \mathrm{kg}$ dw, respectively) compared to adults of both species (738 and $547 \mathrm{mg} / \mathrm{kg} \mathrm{dw}$, respectively), the difference was statistically significant. Ultimately, the correlation between bone $\mathrm{F}^{-}$concentration and the age of foxes and raccoon dogs turned out to be insignificant. One reason for this result could be a very large span of $\mathrm{F}^{-}$concentrations in the bones of the examined specimens.

Summarized, uncontrolled uptake of fluoride released by industry represents a significant health problem both for humans and animals living in polluted areas [38]. Our study shows that the assessment of hazards created by industrial emitters can be conducted conveniently by the measurements of fluorine content in hard tissues of wild animals. Due to the availability of such type of material for studies, it seems that the analysis of fluoride content in bones can be a good tool in the development of ecotoxicology.

Acknowledgments The project was funded by the National Science Centre allocated on the basis of decision number DEC-2011/01/N/N27/ 04256 .

Open Access This article is distributed under the terms of the Creative Commons Attribution License which permits any use, distribution, and reproduction in any medium, provided the original author(s) and the source are credited.

\section{References}

1. Dobrzanski Z, Gorecka H (2001) Fluorine in poultry nutrition. Drobiarstwo Pol 3:13-15

2. Inoue M, LeGeros RZ, Inoue M, Riviera RS, Sathi GA, Tsujigiwa H et al (2006) Fluoride supplement affects bone mineralization in young rats. J Hard Tissue Biol 15:61-64

3. Ghosh A, Mukherjee K, Ghosh SK, Saha B (2013) Sources and toxicity of fluoride in the environment. Res Chem Intermed 39: 2881-2915

4. Harrison PTC (2005) Fluoride in water: a UK perspective. J Fluor Chem 126:1448-1456

5. Verkerk RHJ (2010) The paradox of overlapping micronutrient risk and benefits obligates risk/benefit analysis. Toxicology 278:27-38

6. Vieira AP, Mousny M, Maia R, Hancock R, Everett ET, Grynpas MD (2005) Assessment of teeth as biomarkers for skeletal fluoride exposure. Osteoporos Int 16:1576-1582

7. Piatowska D (ed) (2002) The outline karyology. Issue 1. Med Tour Pres International, Warsaw

8. Bezerra de Menezes LM, Volpato MC, Rosalen PL, Cury JA (2003) Bone as a biomarker of acute fluoride toxicity. Forensic Sci Int 137: 209-214

9. Apostoli P (1992) Criteria for the definition of reference values for toxic metals. Sci Total Environ 120:23-37

10. Kalisińska E, Palczewska M (2007) Fluoride in the teeth of the red fox Vulpes vulpes from western Pomerania. Ochr Srod Zas Nat 31: 428-433

11. Kalisińska E, Palczewska-Komsa M (2011) Teeth of the red fox Vulpes vulpes (L., 1758) as a bioindicator in studies on fluoride pollution. Acta Theriol 56:343-351

12. Walton KC (1984) Fluoride in fox bone near an aluminium reduction plant in Anglesey, Wales and elsewhere in the United Kingdom. Environ Pollut B 7:273-280

13. Goldyn B, Hromada MA, Surmacki A, Tryjanowski P (2003) Habitat use and diet of the red fox Vulpes vulpes in an agricultural landscape in Poland. Zeitschr Jagwis 49:191-200

14. Goszczynski J (1995) Monograph nature and hunting. Fox. Oikos, Warsaw

15. Kauhala K, Laukkanen P, von Rege I (1998) Summer food composition and food niche overlap of the raccoon dog, red fox and badger in Finland. Ecography 21:457-463

16. Kauhala K, Kowalczyk R (2011) Invasion of the raccoon dog Nyctereutes procyonoides in Europe: history of colonization, features behind its success, and threats to native fauna. Curr Zool 57:584-598 
17. Oerlemans M, Koene P (2008) Possible implications of the presence of the raccoon dog (Nyctereutes procyonoides) in the Netherlands. Lutra 51:123-131

18. Kauhala K, Auniola M (2001) Diet of raccoon dogs in summer in the Finnish archipelago. Ecography 24:151-156

19. Swiecicka N, Kubacki S, Zawiślak J, Gulda D, Monkiewicz M, Drewka M (2011) Raccoon dog and raccoon as expansive species in Poland. Prz Hodowlany 6:10-12

20. Melis C, Nordgard H, Herfindal I, Kauhala K, Ahlen PA, Strann KB et al (2007) Raccoon dogs in Norway-potential expansion rate, distribution area and management implications. NTNU Vitenskapsmusset Rapp Zool Ser 2007-3:1-49

21. Reichholf J (1996) Lexicon of natural sciences. Mammals. GeoCenter, Warsaw

22. Dabrowska E, Balunowska M, Letko R (2001) Dangers connected with excessive supply of fluorine. A review. Nowa Stomat 4:22-27

23. Telesiński A, Snioszek M, Sroda E (2011) Fluoride accumulation in chosen hydromacrophytes species depending on their content in water and sediments of Gunica river. Ochr Srod Zas Nat 49:345-353

24. Kalisińska E, Budis H, Lanocha N, Podlasinska J, Jedrzejewska E, Kosik-Bogacka DI (2012) Comparison of hepatic and nephric total mercury concentrations between feral and ranch American mink (Neovison vison) from northwestern Poland. Bull Environ Contam Toxicol 88:802-806

25. Boszke L, Sobczynski T, Glosinska D, Kowalski A, Siepak J (2004) Distribution of mercury and other heavy metals in bottom sediments of middle part Odra River (Germany/Poland). Pol J Environ Stud 13: 495-502

26. Knowlton FF, Whittemore SL (2001) Pulp cavity-tooth width ratios from known-age and wild-caught coyotes determined by radiography. Wildl Soc Bull 29:239-244

27. Sillero-Zubiri C, Hoffmann M, Macdonald DW (eds) (2004) Canids: foxes, wolves, jackals and dogs. Status survey and conservation action plan. IUCN/SSC Canid Specialist Group, Gland, Switzerland and Cambridge, UK, pp 1-430

28. Gutowska I, Bosiacka-Baranowska I, Rybicka M, Dudzińska W, Marchlewicz M, Noceń I et al (2009) Changes in the concentration of fluoride and biogenic elements in the serum and bones of female rats with streptozotocin-induced diabetes. Fluoride 42:11-18
29. Gutowska I, Bosiacka-Baranowska I, Rybicka M, Nocen I, Dudzinska W, Marchlewicz M et al (2011) Changes in the concentration of microelements in the teeth of rats in final stage of type 1 diabetes, with an absolute lack of insulin. Biol Trace Elem Res 139: 332-340

30. Gutowska I, Bosiacka-Baranowska I, Nocen I, Piotrowska K, Marchlewicz M, Wiernicki I et al (2012) Soy isoflavones administered pre- and postnatally may affect the ER $\alpha$ and ER $\beta$ expression and elements content in bones of mature male rats. Hum Exp Toxicol 31:346-354

31. Lanocha N, Kalisińska E, Kosik-Bogacka DI, Budis H, Sokolowski S, Bohatyrewicz A (2013) Comparison of metal concentrations in bones of long-living mammals. Biol Trace Elem Res 152:195-203

32. Budis H, Kalisińska E, Lanocha N, Kosik-Bogacka DI (2013) The concentration of manganese, iron and strontium in bone of red fox Vulpes vulpes (L. 1758). Biol Trace Elem Res 155:361-369

33. Kay CE, Tourangeau PC, Gordon CC (1975) Fluoride levels in indigenous animals and plants collected from uncontaminated ecosystems. Fluoride 8:125-133

34. Gutowska I, Machoy Z, Chlubek D, Machaliński B (2004) Living conditions of deer in the provinces of Western Pomerania and Lubuskie as revealed by mandibular content of fluoride, calcium and magnesium. II Detailed statistical analysis with the statistica neural networks software. Ann Acad Med Stetin 50(Suppl 1):47-53

35. Gutowska I, Machoy Z, Machaliński B, Chlubek D (2004) Living conditions of deer in the provinces of Western Pomerania and Lubuskie as revealed by mandibular content of fluoride, calcium, and magnesium. I. Inter-relations between fluoride, calcium, and magnesium content in mandible. Ann Acad Med Stetin 50(Suppl 1):42-46

36. Zakrzewska H, Machoy-Mokrzynska A, Materny M, Gutowska I, Machoy Z (2005) Estimation of fluoride distribution in the mandible and teeth of the red deer (Cervus elaphus L.) from industrially polluted areas in Poland. Arch Oral Biol 50:309-316

37. Dabkowska E, Machoy-Mokrzyńska A, Straszko J, Machoy Z, Samujło D (1995) Temporal changes in the fluoride levels of jaws of European deer in industrial regions of Western Pomerania, Poland. Environ Geochem Health 17:155-158

38. Machoy Z, Straszko J, Dziedziejko V, Gutowska I (2002) Estimation of influence of industrial emissions on fluoride accumulation in deers jaws by neural network. Environ Sci 9:289-300 